\title{
THE MANITOBA LAND CALCULATOR: A TOOL TO ESTIMATE LAND REQUIREMENTS FOR MANURE APPLICATION IN MANITOBA, CANADA
}

\author{
Roniele Cordeiro', Petra Loro ${ }^{2, *}$, Marcos Cordeiro ${ }^{3}$, \\ Clay Sawka ${ }^{2}$, Kim Ominski ${ }^{3}$, Don Flaten ${ }^{4}$ \\ ${ }^{1}$ Prairie Agricultural Machinery Institute (PAMI), Portage la Prairie, Manitoba, Canada. \\ ${ }^{2}$ Manitoba Agriculture and Resource Development, Winnipeg, Manitoba, Canada. \\ ${ }^{3}$ Department of Animal Science, University of Manitoba, Winnipeg, Manitoba, Canada \\ ${ }^{4}$ Department of Soil Science, University of Manitoba, Winnipeg, Manitoba, Canada. \\ *Correspondence: petra.loro@gov.mb.ca.
}

\section{HighLIGHTS \\ - The Manitoba Land Calculator is a tool to estimate land requirements for new and expanding livestock operations. \\ - This new tool reflects Manitoba production practices and recent advances in animal and crop performance. \\ - Considerably more land is needed for management of manure phosphorus than when only nitrogen is considered. \\ - Sufficient land for application of manure supports the environmental sustainability of livestock production.}

\begin{abstract}
The planning of new livestock and poultry facilities or expansion of existing facilities should ensure sufficient land for manure application. Decision support tools used to establish land requirements for manure nutrients should take into consideration advances in animal genetics, performance, feeding strategies, and available feeds. This article presents a new tool for estimating land requirements for new and expanding pig, beef, dairy, and poultry operations in the province of Manitoba, Canada. The Manitoba Land Calculator (MLC) estimates land requirements for manure nitrogen (N) and phosphorus (P). It uses a mass balance approach to estimate nutrient excretion by livestock and poultry based on typical Manitoba feeding practices, weight gain, and production cycles. Crop nutrient utilization and removals can be calculated for 20 common crops grown in Manitoba using reliable long-term yields and farm-specific crop areas. Two case studies (pig and poultry) were selected from the Livestock Technical Review Public Registry on the Government of Manitoba website to illustrate the inputs and outputs associated with the MLC. The results indicated that land requirements increased by 4.6-fold and 5.7-fold for the poultry and pig operations, respectively, compared to the previous provincial methodology due to the inclusion of $P$ in the model. Securing additional land during the planning stages will support the implementation of nutrient stewardship principles that ensure the long-term environmental sustainability of livestock operations.
\end{abstract}

Keywords. Animal production, Land requirements, Livestock and poultry, Manure, Mass balance, Nutrient excretion.

A gricultural systems are facing significant pressure to increase productivity to meet the food demand of a growing population (Delgado et al., 2019). Satisfying the food demand resulting from population growth will require an increase in both crop and animal production (Alexandratos and Bruinsma, 2012; Delgado et al., 2019; Mottet et al., 2017). While livestock products are critical to meet future food demand, animal production systems have been under increasing scrutiny due to their potential negative impacts on the environment. Pollution from manure is the primary environmental concern

(c) (1) $\Theta$ The authors have paid for open access for this article. This c. ${ }_{\mathrm{BY}} \mathrm{NC}_{\mathrm{ND}}$ work is licensed under a Creative Commons AttributionNonCommercial-NoDerivatives 4.0 International License https://creative commons.org/licenses/by-nc-nd/4.0

Submitted for review on 5 April 2021 as manuscript number PAFS 14613; approved for publication as a Research Article by the Plant, Animal, \& Facility Systems Community of ASABE on 26 July 2021.
(Subbotin et al., 2017). While manure is an excellent source of nutrients for crop production (Long et al., 2018; Thayer et al., 2012; Yang et al., 2016), excess $\mathrm{N}$ and P build up in soils when manure is applied above crop nutrient requirements, increasing the risk of loss to surface and groundwater (Lory et al., 2008; van Dijk et al., 2016; Velthof et al., 2014). However, this dynamic depends on manure nutrient availability (Lory et al., 2008), which can vary spatially and temporally (Andersen and Pepple, 2017).

To improve the environmental sustainability of livestock and poultry production and to mitigate potential negative environmental impacts, beneficial nutrient management practices are needed. The 4R nutrient stewardship framework (right source, right rate, right timing, and right placement) is intended to maximize crop uptake and minimize losses of nutrients (Cordeiro et al., 2016). Among the 4Rs, the application rate is one of the most important factors affecting nutrient losses from manured land (Ontkean et al., 2006). In some instances, the application rate has been deemed more 
influential than timing, method of application, and mineralization rates (Dinnes et al., 2002; Power and Schepers, 1989).

Sufficient land is critical for sustainable manure application rates over the long-term. One method of accurately estimating land requirements for livestock and poultry operations is to balance nutrient excretion by the livestock and poultry with nutrient utilization and/or removal by the crops grown on the land receiving the manure. Several tools exist to estimate nutrient excretion from livestock and poultry. For example, the Integrated Farm System Model (IFSM) uses process-based simulations to estimate nutrient excretion in beef and dairy operations (Rotz et al., 2012). ASABE Standard D384.2 (ASABE, 2005) provides an equation-based approach using empirical data that integrates animal feeding practices and performance into final estimates for total solids and $\mathrm{N}$ and $\mathrm{P}$ excretion for seven livestock and poultry species (Koelsch, 2006). Mass balance methodologies have also been developed for estimating manure nutrient excretion (Angel et al., 2003; Applegate et al., 2003).

Nutrient management tools are critical for environmental sustainability in livestock and poultry-intensive areas, such as some areas in the Province of Manitoba in Canada (Loro et al., 2013). Manitoba accounts for $4 \%, 11 \%, 24 \%$, and $6 \%$ of the total Canadian production of dairy, beef, pigs, and chickens (broiler and layers), respectively (Canada, 2020), but this production is expected to increase due to provincial strategies aimed at sustainably increasing livestock and poultry production in Manitoba by 35\% (Manitoba, 2019). To facilitate sustainable livestock and poultry expansion, the Government of Manitoba has developed the Manitoba Land Calculator (MLC), a user-friendly tool that estimates the amount of land needed for long-term management of the manure $\mathrm{N}$ and $\mathrm{P}$ generated by livestock and poultry operations. The objectives of this article are to describe the MLC and present two case studies comparing land requirements estimated by the MLC and by the previous methodology used by the province.

\section{Materials AND Methods \\ MANITOBA LAND CALCULATOR (MLC)}

The MLC is a tool developed and currently used by Manitoba Agriculture and Resource Development to estimate the provincial land requirements for new and expanding livestock and poultry operations that are seeking municipal approval to build livestock and poultry facilities. The MLC is Microsoft Excel-based and is comprised of two major sections: (1) livestock and poultry nutrient excretion, and (2) crop nutrient uptake and removal. Nutrient excretion can be estimated for pig (P), beef (B), dairy (D), and poultry (Po) operations (table 1). All livestock and poultry categories can be combined into a single farm, and the total nutrient excretion of the farm can be estimated. The MLC uses a mass balance approach in which the nutrients excreted in manure are the difference between the nutrients ingested in feed and the combined amount of nutrients retained as weight gain and exported in production (i.e., milk for dairy cows and eggs for laying hens). Crop nutrient uptake and removal can be estimated for 20 crops based on cropped area, realistic long-term yields, and crop nutrient concentrations (table 2). Finally, the land base required for any
Table 1. Livestock and poultry categories and respective operations and feeding groups in the Manitoba Land Calculator (MLC).

\begin{tabular}{|c|c|c|}
\hline Category & $\begin{array}{c}\text { Operation } \\
\text { Type }^{[\mathrm{a}]}\end{array}$ & Feeding Group \\
\hline Pig & NA & Gestating sow \\
\hline \multirow[t]{8}{*}{ (P) } & NA & Nursing sow \\
\hline & NA & Nursing litter \\
\hline & NA & Live cull sow \\
\hline & NA & Bred gilt \\
\hline & NA & Gilts (purchased) \\
\hline & NA & Boars \\
\hline & NA & Weanlings/nursery \\
\hline & NA & Growers/finishers \\
\hline \multirow{9}{*}{$\begin{array}{l}\text { Beef } \\
\text { (B) }\end{array}$} & Cow calf & Mature cows $(>2$ years old $)$ \\
\hline & Cow calf & Bred heifer (14 months to 2 years) \\
\hline & Cow calf & Replacement heifers ( 7 to 14 months) \\
\hline & Cow calf & Nursing calves ( 0 to 7 months) \\
\hline & Cow calf & Bulls \\
\hline & Feeder & Feedlot cattle, long keep \\
\hline & Feeder & Feedlot cattle, short keep \\
\hline & Feeder & Backgrounders, pasture \\
\hline & Feeder & Backgrounders, confined \\
\hline \multirow{6}{*}{$\begin{array}{l}\text { Dairy } \\
\text { (D) }\end{array}$} & NA & Lactating mature cows \\
\hline & NA & Lactating first calf heifer \\
\hline & NA & Dry cows \\
\hline & NA & Calves, 0 to 3 months \\
\hline & NA & Calves, 4 to 13 months \\
\hline & NA & Replacement, $>13$ months \\
\hline \multirow{21}{*}{$\begin{array}{l}\text { Poultry } \\
\text { (Po) }\end{array}$} & Chicken & Light broilers \\
\hline & Chicken & Broilers \\
\hline & Chicken & Broiler breeder pullets \\
\hline & Chicken & Broiler breeder hens \\
\hline & Eggs & White layer pullets \\
\hline & Eggs & White layer hens \\
\hline & Eggs & White breeder pullets \\
\hline & Eggs & White breeder hens \\
\hline & Eggs & Brown layer pullets \\
\hline & Eggs & Brown layer hens \\
\hline & Eggs & Brown breeder pullets \\
\hline & Eggs & Brown breeder hens \\
\hline & Turkey & Broiler turkey (0 to 9 weeks) \\
\hline & Turkey & Hen turkey ( 0 to 11 weeks) \\
\hline & Turkey & Heavy hens ( 0 to 14 weeks $)$ \\
\hline & Turkey & Toms ( 0 to 14 weeks $)$ \\
\hline & Turkey & Breeding hen growers ( 0 to 30 weeks) \\
\hline & Turkey & Breeding hens ( 31 end of lay) \\
\hline & Turkey & Breeding tom grower ( 0 to 17 weeks) \\
\hline & Turkey & Breeding tom grower ( 17 to 30 weeks) \\
\hline & Turkey & Breeding tom (31 end of lay) \\
\hline
\end{tabular}

new and expanding livestock and poultry operation is calculated using the total nutrient excretion for the farm and the average nutrient uptake and removal for the crop rotation.

A combination of user-defined animal and crop inputs (table 3), optional default values, constants (table 4), and a series of equations (table 5) comprises the workflow of the MLC (fig. 1). The user must input the total number of animals in each animal category and the type of manure storage system to estimate $\mathrm{N}$ losses from the housing system and storage. Default values are provided for animal weights but can be modified by the user for some categories of beef and poultry, as these livestock and poultry systems have a wide range of production practices. Similarly, the number of days on feed per cycle and the number of cycles per year also have default values that can be adjusted for beef and poultry (table 3). The required user-defined crop inputs include the land area for each crop grown and the respective realistic long-term average yield for each crop (table 2). 
Table 2. Nitrogen and phosphorus concentrations in western Canada crops (adapted from Manitoba, 2009).

\begin{tabular}{ccc}
\hline Crop & $\begin{array}{c}\mathrm{P}_{2} \mathrm{O}_{5} \mathrm{Removal}^{[\mathrm{a}]} \\
\left(\mathrm{kg} \mathrm{Mg}^{-1}\right)\end{array}$ & $\begin{array}{c}\mathrm{N} \mathrm{Uptake}^{[\mathrm{b}]} \\
\left(\mathrm{kg} \mathrm{Mg}^{-1}\right)\end{array}$ \\
\hline Alfalfa & 6.9 & 29 \\
Barley grain & 8.8 & 29 \\
Barley silage & 5.9 & 17.2 \\
Canola & 20.8 & 63.8 \\
Corn grain & 7.9 & 27.3 \\
Corn silage & 6.4 & 15.6 \\
Dry edible beans & 13.9 & - \\
Fababeans & 17.9 & 84 \\
Flax & 11.6 & 51.4 \\
Grass hay & 5.0 & 17.1 \\
Lentils & 10.3 & 50.8 \\
Oats & 8.1 & 33.4 \\
Pasture (grazed) & 5.0 & 17.1 \\
Peas & 11.5 & 51 \\
Potatoes & 0.9 & 5.7 \\
Rye & 8.0 & 29.8 \\
Soybeans & 14.0 & 86.7 \\
Sunflower & 11.0 & - \\
Spring wheat & 9.8 & 35.2 \\
Winter wheat & 8.5 & 22.5 \\
\hline
\end{tabular}

[a] $\mathrm{P}$ removal in the harvested portion of the crop is used because repeated applications of manure above crop removal rates result in long-term buildup of soil test $\mathrm{P}$ and increased risk to surface water.

[b] $\mathrm{N}$ uptake by the crop, which is larger than $\mathrm{N}$ removal, is used to more accurately estimate the land needed for N-based manure application rates, which are the standard in Manitoba.

Table 3. Inputs required by the MLC for estimating nutrient excretion for the pig (P), beef (B), dairy (D) and poultry (Po) categories.

\begin{tabular}{|c|c|c|}
\hline Input & Description & Categories $^{[\mathrm{a}]}$ \\
\hline 1 & Manure storage and treatment ${ }^{[\mathrm{b}]}$ & $\mathrm{P}, \mathrm{B}, \mathrm{D}, \mathrm{Po}$ \\
\hline 2 & Number of animals (places) & $\mathrm{P}, \mathrm{B}, \mathrm{D}, \mathrm{Po}$ \\
\hline 3 & Weight in $(\mathrm{kg})^{[\mathrm{c}]}$ & $\mathrm{P}, \mathrm{B}, \mathrm{D}, \mathrm{Po}$ \\
\hline 4 & Weight out $(\mathrm{kg})^{[\mathrm{c}]}$ & $\mathrm{P}, \mathrm{B}, \mathrm{D}, \mathrm{Po}$ \\
\hline 5 & Days on feed per cycle ${ }^{[\mathrm{c}],[\mathrm{d}]}$ & $\mathrm{B}, \mathrm{Po}$ \\
\hline 6 & Number of cycles per year ${ }^{[\mathrm{c}],[\mathrm{d}]}$ & $\mathrm{B}, \mathrm{Po}$ \\
\hline
\end{tabular}

[a] Each input applies to all categories listed.

[b] The storage type, defined by the user, generates $\mathrm{N}$ volatilization values as follows: $10 \%$ of the total $\mathrm{N}$ in the manure for in-barn losses and covered liquid storage; $20 \%$ for uncovered liquid storage in steel or concrete tanks, solid manure sheds, and manure pack with no field storage; $30 \%$ for uncovered liquid storage in earthen structures or mole hills (a system used in dairy production in Canada in which manure is pushed or pumped into an engineered storage and stacks as the liquid fraction pools around the solids); and $40 \%$ for compost, field storage, mechanically dried manure, and manure deposited on pasture.

[c] For these inputs, defaults are provided but can be modified by the user for beef and poultry operations.

[d] For pig and dairy operations, these variables are constants (table 4).

The MLC sequentially calculates the livestock and poultry average weight, weight gain per cycle (table 5, eqs. 1 and 2) and feed consumption per day for beef and dairy (as a percentage of body weight, table 5, eq. 3). For pigs, feed consumption rates are constants (table 4, constants 2 and 3 ). The MLC converts feed consumption to protein consumed per animal per day (table 5, eq. 4) and per cycle (table 5, eq. 5) based on the typical protein content of Manitoba feeds and then into feed $\mathrm{N}$ consumed per animal per cycle (table 5, eq. 6). Feed $\mathrm{P}$ consumed per animal per day (table 5, eq. 7) and per cycle (table 5, eq. 8) is also estimated using the typical P content of Manitoba feeds. The MLC estimates milk consumption (table 5 , eq. 9 ) by young stock (i.e., nursing pig litters and beef calves, table 1) to account for the nutrients lost by the sow/dam via milk production (table 5, eqs. 10 to 16 ).
The total amounts of $\mathrm{N}$ and $\mathrm{P}$ retained in animal weight gain (table 5, eqs. 17 and 18), as well as the $\mathrm{N}$ and $\mathrm{P}$ exported in dairy milk (table 5, eqs. 19 and 20) and eggs (table 5, eqs. 21 and 22), are estimated per cycle using literature values for $\mathrm{N}$ and $\mathrm{P}$ in whole animals, milk, and eggs (table 4, constants 10,13,14,15,17, and 18). Total retention for the cycle is then summed for all livestock and poultry (table 5, eqs. 23 and 24). The MLC estimates the amounts of nutrients excreted as the difference between the total amounts of $\mathrm{N}$ and $\mathrm{P}$ consumed and the total amounts retained (table 5, eqs. 25 and 30 ) per cycle (table 5, eqs. 26 and 31 ) and per year (table 5, eq. 27). Phosphorus excreted is converted to $\mathrm{P}_{2} \mathrm{O}_{5}$ excreted per cycle, per year, and per flock or herd per year (table 5, eqs. 32 to 34 ) to be consistent with crop removals, which are expressed in $\mathrm{P}_{2} \mathrm{O}_{5}$. The total $\mathrm{N}$ excreted is adjusted for volatilization losses in the animal housing and during storage (table 5, eq. 29). The $\mathrm{P}$ and volatilization-adjusted $\mathrm{N}$ excreted are then balanced with crop $\mathrm{P}$ removal and crop $\mathrm{N}$ uptake to generate the land requirements. The MLC does not make recommendations for application rate based on timing, form, and method of application. For that, farmers in Manitoba prepare manure management plans (Manitoba, 2021a) that consider specific aspects of manure handling, nitrogen volatilization due to land application, residual soil nutrient values, and specific crop nutrient requirements.

\section{FARM PRACTICES GUIDELINES (FPG)}

The Farm Practices Guidelines (FPG) for livestock and poultry producers in Manitoba (Manitoba, 1994, 1995a, 1995b, 1998a, 2000) described manure management systems and practices for pig, beef, dairy, and poultry operations that reduced the risk of pollution and minimized odor experienced by neighbors. They contained the former methodology used by the Province of Manitoba for estimating the land requirements for new and expanding livestock and poultry operations. This methodology was used in the 1990s and early 2000s when the main public concern was excess application of manure $\mathrm{N}$ that could result in nitrate contamination of groundwater.

In contrast to the MLC, the FPG estimated land requirements based on $\mathrm{N}$ only. The FPG used a simple five-step calculation that required animal numbers and days on feed as inputs (fig. 2) and knowledge of the manure and cropping systems. The number of animals was converted to animal units (AU) derived from ASABE Standard D384.1. (ASABE, 2003) using daily $\mathrm{N}$ excretion values for dairy, beef, pigs, layers, broilers, and turkeys $(0.45,0.34,0.52$, $0.84,1.1$, and $0.62 \mathrm{~kg}$ per $1000 \mathrm{~kg}$ live animal weight per day, respectively) adjusted to achieve $73 \mathrm{~kg} \mathrm{~N}$ excreted year ${ }^{-1}$. The pig AU were further adjusted to account for Manitoba feeding practices using the broad assumption that $70 \%$ of the $\mathrm{N}$ consumed was excreted (Manitoba, 1998a). The land requirements for new and expanding livestock and poultry operations were estimated in the FPG by adjusting the AU using a series of multiplication factors to account for $\mathrm{N}$ losses related to various storage and management practices (table 6) and crop $\mathrm{N}$ utilization for annual and perennial crops on light, medium, and heavy textured soils when manure was applied in the spring or fall (table 7). 
Table 4. Constants used by the MLC to estimate nutrient excretion for pig (P), beef (B), dairy (D), and poultry (Po) operations.

\begin{tabular}{|c|c|c|c|c|c|}
\hline Constant & Description & Units & Categories & Range $^{[\mathrm{a}]}$ & Source $^{[\mathrm{b}]}$ \\
\hline 1 & $\begin{array}{l}\text { Average daily milk } \\
\text { production per cow } \\
{[\mathrm{c}]}\end{array}$ & $\mathrm{kg} \mathrm{d}^{-1}$ & $\mathrm{D}$ & 28 to 31 & CanWest DHI (2018) \\
\hline 2 & $\begin{array}{l}\text { Feed consumed per } \\
\text { animal per day }\end{array}$ & $\mathrm{kg} \mathrm{d}^{-1}$ & $\mathrm{P}^{[\mathrm{d}]}$ & 2.3 to 6.5 & NRC (2012); PIC (2013) \\
\hline \multirow[t]{2}{*}{3} & \multirow{2}{*}{$\begin{array}{l}\text { Feed consumed per } \\
\text { animal per cycle }\end{array}$} & \multirow[t]{2}{*}{$\mathrm{kg} \mathrm{cycle}^{-1}$} & $\mathrm{P}^{[\mathrm{e}]}$ & 34 to 308 & NRC (2012) \\
\hline & & & Po & 2.61 to 157.5 & Amy Johnston, ARD, pers. comm. (20 Oct. 2019) \\
\hline \multirow[t]{2}{*}{4} & \multirow[t]{2}{*}{$\begin{array}{l}\text { Feed consumed per } \\
\text { animal per day }\end{array}$} & \multirow[t]{2}{*}{$\begin{array}{l}\% \text { of body } \\
\text { weight }\end{array}$} & $\mathrm{B}$ & 2.1 to 2.7 & $\begin{array}{l}\text { Kim Ominski, University of Manitoba, pers. comm. } \\
\text { (23 Jan. 2015); Yurchak and Okine (2004) }\end{array}$ \\
\hline & & & $\mathrm{D}$ & 2.0 to 3.7 & NRC (2001) \\
\hline \multirow[t]{2}{*}{5} & \multirow[t]{2}{*}{ Days until weaned } & \multirow[t]{2}{*}{ days } & $\mathrm{P}$ & 21 & Robyn Harte, ARD, pers. comm. (20 Nov. 2019) \\
\hline & & & B & 210 & $\begin{array}{l}\text { Kim Ominski, University of Manitoba, pers. comm. } \\
\text { (23 Jan. 2015) }\end{array}$ \\
\hline \multirow[t]{4}{*}{6} & \multirow[t]{4}{*}{ Crude protein $^{[\mathrm{f}]}$} & \multirow[t]{4}{*}{$\%$} & $\mathrm{P}$ & 14 to 20 & Robyn Harte, ARD, pers. comm. (20 Nov. 2019) \\
\hline & & & $\mathrm{B}$ & 10 to 12 & Kopp et al. (2004) \\
\hline & & & $\mathrm{D}$ & 10.7 to 22.5 & $\begin{array}{l}\text { Plaizier et al. (2004) } \\
\end{array}$ \\
\hline & & & Po & 11 to 23 & Amy Johnston, ARD, pers. comm. (20 Oct. 2019) \\
\hline 7 & $\begin{array}{l}\text { Milk consumed per } \\
\text { piglet per day }\end{array}$ & $\mathrm{g}$ & $\mathrm{P}$ & 900 & Adapted from Noblet and Etienne (1989) \\
\hline 8 & $\begin{array}{l}\text { Milk consumed per } \\
\text { beef calf per day }\end{array}$ & $\mathrm{kg}$ & $\mathrm{B}$ & 5.8 & Kopp et al. (2004) \\
\hline \multirow[t]{2}{*}{9} & \multirow{2}{*}{$\begin{array}{l}\text { Protein content of } \\
\text { milk for young stock }\end{array}$} & \multirow[t]{2}{*}{$\%$} & $\mathrm{P}$ & 5.3 & Csapó et al. (1996) \\
\hline & & & $\mathrm{B}$ & 3.8 & Kopp et al. (2004) \\
\hline \multirow[t]{4}{*}{10} & \multirow[t]{4}{*}{$\mathrm{N}$ content per kg gain } & \multirow[t]{4}{*}{ g kg gain $^{-1}$} & $\mathrm{P}$ & 26 & Bikker and Blok (2017) \\
\hline & & & $\mathrm{B}$ & 26 & Tamminga (2006) \\
\hline & & & $\mathrm{D}$ & 27 & Andrew et al. (1994) \\
\hline & & & Po & 26 to 35 & $\begin{array}{c}\text { Liu et al. (2017); dos Santos et al. (2017); } \\
\text { de Avila et al. (2003); Robinson and Robinson (1991) }\end{array}$ \\
\hline \multirow[t]{4}{*}{11} & \multirow[t]{4}{*}{$\mathrm{P}$ content of feed } & $\%$ & $\mathrm{P}$ & 0.46 to 0.64 & Manitoba (2013); Robyn Harte, pers. comm. (20 Nov. 2019) \\
\hline & & & $\mathrm{B}$ & 0.19 to 0.33 & Kopp et al. (2004) \\
\hline & & & $\mathrm{D}$ & 0.22 to 0.48 & NRC (2001); Plaizier et al. (2004) \\
\hline & & & Po & 0.51 to 0.78 & Amy Johnston, ARD, pers. comm. (20 Oct. 2019) \\
\hline 12 & $\mathrm{P}$ content of milk & $\%$ & $\mathrm{P}$ & 0.15 & Bikker and Blok (2017) \\
\hline & for young stock & & $\mathrm{B}$ & 0.12 & Hidiroglou and Proulx (1982) \\
\hline 13 & $\mathrm{P}$ content per kg gain & g kg gain $^{-1}$ & $\mathrm{P}$ & 5.3 to 5.8 & Bikker and Blok (2017) \\
\hline & & & $\mathrm{B}$ & 7.1 & Tamminga (2006); Gibson et al. (2002) \\
\hline & & & $\mathrm{D}$ & 8.3 & Marcondes et al. (2010) \\
\hline & & & Po & 4 to 6.6 & $\begin{array}{c}\text { Lambert et al. (2014); Shastak et al. (2012); } \\
\text { Applegate et al. (2008) }\end{array}$ \\
\hline 14 & $\begin{array}{l}\text { Protein content of } \\
\text { milk for market }\end{array}$ & $\%$ & $\mathrm{D}$ & 3.3 & CanWest DHI (2018) \\
\hline 15 & $\begin{array}{l}\mathrm{P} \text { content of } \\
\text { milk for market }\end{array}$ & $\%$ & $\mathrm{D}$ & 0.09 & Goselink et al. (2015); Plaizier et al. (2004) \\
\hline 16 & $\begin{array}{l}\text { Number of eggs } \\
\text { per bird per cycle }\end{array}$ & $\mathrm{n}$ & Po & 118 to 330 & Amy Johnston, ARD, pers. comm. (20 Oct. 2019) \\
\hline 17 & $\mathrm{~N}$ content of egg & $\mathrm{g} \mathrm{egg}^{-1}$ & Po & 1.16 to 1.7 & Manitoba (2021b); Halley (2016); Ghane et al. (2015) \\
\hline 18 & $P$ content of egg & $\mathrm{g} \mathrm{egg}^{-1}$ & Po & 0.09 to 0.21 & $\begin{array}{l}\text { Lambert et al. (2014); Neijat et al. (2011); } \\
\text { Adeyeye (2009); Godwin et al. (2005) }\end{array}$ \\
\hline 19 & $\begin{array}{c}\text { Conversion factor } \\
\text { for protein to } \mathrm{N}\end{array}$ & & $\mathrm{P}, \mathrm{B}, \mathrm{D}, \mathrm{Po}$ & 6.25 & - \\
\hline 20 & $\begin{array}{l}\text { Conversion factor } \\
\text { for } \mathrm{P} \text { to } \mathrm{P}_{2} \mathrm{O}_{5}\end{array}$ & & $\mathrm{P}, \mathrm{B}, \mathrm{D}, \mathrm{Po}$ & 2.29 & - \\
\hline 21 & $\begin{array}{l}\text { Number of piglets } \\
\text { per litter }\end{array}$ & $n$ & $\mathrm{P}$ & 13.2 & Manitoba (2019) \\
\hline 22 & Number of cycles & $n$ & $\mathrm{P}$ & 1.0 to 26.1 & - \\
\hline & per year ${ }^{[\mathrm{g}]}$ & & $\mathrm{B}$ & 1.0 & \\
\hline & & & $\mathrm{D}$ & 1.0 to 4.2 & \\
\hline & & & Po & 1.0 to 7.0 & \\
\hline 23 & Days on feed & days & $\mathrm{P}$ & 14 to 365 & - \\
\hline & per cycle $\mathrm{e}^{[\mathrm{g}]}$ & & $\mathrm{D}$ & 86 to 348 & \\
\hline Constan & nges include values fo & feeding gro & s within eac & estock and pol & category (table 1), except where noted. \\
\hline "pers. ce & m." indicates personal & nmunication & & & \\
\hline Milk de & ned for market only. & & & & \\
\hline Includes & 11 pig feeding groups ex & t nursery an & grower/finish & igs. & \\
\hline Includes & ursery and grower/finis & & & & \\
\hline Percenta & of feed consumed for & s and poultry & nd percentag & dry matter int & for dairy and beef. \\
\hline For beef & 1 1 $x$ th the & & & & \\
\hline
\end{tabular}


Table 5. Equations used by the MLC to estimate nutrient excretion for pig (P), beef (B), dairy (D), and poultry (Po) operations.

\begin{tabular}{|c|c|c|c|c|}
\hline Equation & Variable & Units & Categories & Mathematical Description $^{[\mathrm{a}]}$ \\
\hline \multicolumn{5}{|c|}{ Livestock and poultry weights } \\
\hline 1 & Average animal weight & $\mathrm{kg}$ & $\mathrm{P}, \mathrm{B}, \mathrm{D}, \mathrm{Po}$ & (Input $3+$ Input 4) / 2 \\
\hline 2 & Weight gain per cycle & kg place $^{-1}$ cycle $^{-1}$ & $\mathrm{P}, \mathrm{B}, \mathrm{D}, \mathrm{Po}$ & Input 4 - Input 3 \\
\hline \multicolumn{5}{|c|}{ Feed consumption } \\
\hline \multirow[t]{3}{*}{3} & Feed consumed per animal per day ${ }^{[b]}$ & $\mathrm{kg} \mathrm{d}^{-1}$ & $\mathrm{P}^{[\mathrm{c}]}$ & Constant 3 / Constant 23 \\
\hline & & & $\mathrm{B}, \mathrm{D}$ & Eq. $1 \times$ Constant 4 \\
\hline & & & Po & Constant 3 / Input 5 \\
\hline \multirow[t]{2}{*}{4} & Feed protein consumed per place per day & $\mathrm{kg} \mathrm{d}^{-1}$ & $\mathrm{P}^{[\mathrm{c}]}, \mathrm{B}, \mathrm{D}, \mathrm{Po}$ & Eq. $3 \times$ Constant 6 \\
\hline & & & $\mathrm{P}^{[\mathrm{d}]}$ & Constant $2 \times$ Constant 6 \\
\hline \multirow[t]{2}{*}{5} & Feed protein consumed per place per cycle & $\mathrm{kg} \mathrm{cycle}^{-1}$ & $\mathrm{~B}, \mathrm{Po}$ & Eq. $4 \times$ Input 5 \\
\hline & & & $\mathrm{P}, \mathrm{D}$ & Eq. $4 \times$ Constant 23 \\
\hline 6 & Feed $\mathrm{N}$ consumed per place per cycle & $\mathrm{kg} \mathrm{cycle}^{-1}$ & $\mathrm{P}, \mathrm{B}, \mathrm{D}, \mathrm{Po}$ & Eq. 5 / Constant 19 \\
\hline \multirow[t]{2}{*}{7} & Feed $\mathrm{P}$ consumed per place per day & $\mathrm{kg} \mathrm{d}^{-1}$ & $\mathrm{P}^{[\mathrm{d}]}$ & Constant $2 \times$ Constant 11 \\
\hline & & & $\mathrm{P}^{[\mathrm{c}]}, \mathrm{B}, \mathrm{D}, \mathrm{Po}$ & Eq. $3 \times$ Constant 11 \\
\hline \multirow[t]{2}{*}{8} & Feed $\mathrm{P}$ consumed per place per cycle & $\mathrm{kg} \mathrm{cycle}^{-1}$ & $\mathrm{P}, \mathrm{D}$ & Eq. $7 \times$ Constant 23 \\
\hline & & & $\mathrm{B}, \mathrm{Po}$ & Eq. $7 \times$ Input 5 \\
\hline \multicolumn{5}{|c|}{ Milk consumption } \\
\hline 9 & Milk consumed per litter per day & $\mathrm{g}$ & $\mathrm{P}$ & Constant $7 \times$ Constant 21 \\
\hline \multirow[t]{2}{*}{10} & Milk protein consumed per litter/calf per day & g litter $^{-1} \mathrm{~d}^{-1}$ & $\mathrm{P}$ & Eq. $9 \times$ Constant 9 \\
\hline & & $\mathrm{kg} \mathrm{calf}^{-1} \mathrm{~d}^{-1}$ & $\mathrm{~B}$ & Constant $8 \times$ Constant 9 \\
\hline \multirow[t]{2}{*}{11} & Milk protein consumed per litter/calf per cycle & kg litter ${ }^{-1}$ cycle $^{-1}$ & $\mathrm{P}$ & $($ Eq. $10 \times$ Constant 5$) / 1000$ \\
\hline & & $\mathrm{kg} \mathrm{calf}^{1}$ cycle $^{-1}$ & $\mathrm{~B}$ & Eq. $10 \times$ Constant 5 \\
\hline 12 & Milk N consumed per litter/calf per cycle & $\mathrm{kg}$ (litter or calf) $)^{-1}$ cycle $^{-1}$ & $\mathrm{P}, \mathrm{B}$ & Eq. $11 /$ Constant 19 \\
\hline \multirow[t]{2}{*}{13} & Milk P consumed per litter/calf per day & $\mathrm{g} \mathrm{litter}^{-1} \mathrm{~d}^{-1}$ & $\mathrm{P}$ & Eq. $9 \times$ Constant 12 \\
\hline & & $\mathrm{kg}$ calf $^{-1} \mathrm{~d}^{-1}$ & B & Constant $8 \times$ Constant 12 \\
\hline \multirow[t]{2}{*}{14} & Milk P consumed per litter/calf per cycle & kg litter ${ }^{-1}$ cycle $^{-1}$ & $\mathrm{P}$ & $($ Eq. $13 \times$ Constant 5$) / 1000$ \\
\hline & & $\mathrm{kg} \mathrm{calf}^{-1}$ cycle $^{-1}$ & $\mathrm{~B}$ & Eq. $13 \times$ Constant 5 \\
\hline \multicolumn{5}{|c|}{ Total consumption } \\
\hline 15 & $\mathrm{~N}$ consumed per place per cycle & $\mathrm{kg} \mathrm{cycle}^{-1}$ & $\mathrm{P}, \mathrm{B}, \mathrm{D}, \mathrm{Po}$ & Eq. $6+$ Eq. 12 \\
\hline 16 & $\mathrm{P}$ consumed per place per cycle & $\mathrm{kg} \mathrm{cycle}^{-1}$ & $\mathrm{P}, \mathrm{B}, \mathrm{D}, \mathrm{Po}$ & Eq. $8+$ Eq. 14 \\
\hline \multicolumn{5}{|c|}{ Retention in weight gain } \\
\hline 17 & $\mathrm{~N}$ retained in weight gain per cycle ${ }^{[e]}$ & $\mathrm{kg} \mathrm{cycle}^{-1}$ & $\mathrm{P}, \mathrm{B}, \mathrm{D}, \mathrm{Po}$ & Constant $10 \times$ Eq. 2 \\
\hline $\begin{array}{r}18 \\
\end{array}$ & P retained in weight gain per cycle ${ }^{[e]}$ & $\mathrm{kg} \mathrm{cycle}^{-1}$ & $\mathrm{P}, \mathrm{B}, \mathrm{D}, \mathrm{Po}$ & Constant $13 \times$ Eq. 2 \\
\hline \multicolumn{5}{|c|}{ Retention in milk and eggs } \\
\hline 19 & $\mathrm{~N}$ exported in milk per cycle & $\mathrm{kg} \mathrm{cycle}^{-1}$ & $\mathrm{D}$ & $\begin{array}{l}\text { Constant } 1 \times \text { Constant } 14 / 100 \\
/ \text { Constant } 19 \times \text { Constant } 23\end{array}$ \\
\hline 20 & $\mathrm{P}$ exported in milk per cycle & $\mathrm{kg} \mathrm{cycle}^{-1}$ & $\mathrm{D}$ & $\begin{array}{c}\text { Constant } 1 \times \text { Constant } 15 \\
/ 100 / \text { Constant } 23\end{array}$ \\
\hline 21 & $\mathrm{~N}$ retained in eggs & $\mathrm{kg} \mathrm{cycle}^{-1}$ & Po & $($ Constant $16 \times$ Constant 17$) / 1000$ \\
\hline 22 & P retained in eggs & $\mathrm{kg} \mathrm{cycle}^{-1}$ & Po & $($ Constant $16 \times$ Constant 18$) / 1000$ \\
\hline Total reten & tion (function of weight gain, milk, and eggs) & & & \\
\hline 23 & $\mathrm{~N}$ retained per cycle & $\mathrm{kg} \mathrm{cycle}^{-1}$ & $\mathrm{P}, \mathrm{B}$ & Eq. $17+$ Eq. 12 \\
\hline & & & $\mathrm{D}$ & Eq. $17+$ Eq. 19 \\
\hline & & & Po & Eq. $17+$ Eq. 21 \\
\hline 24 & P retained per place per cycle & $\mathrm{kg} \mathrm{cycle}^{-1}$ & $\mathrm{P}, \mathrm{B}$ & Eq. $18+$ Eq. 14 \\
\hline & & & $\mathrm{D}$ & Eq. $18+$ Eq. 20 \\
\hline & & & Po & Eq. $18+$ Eq. 22 \\
\hline Excretion & & & & \\
\hline 25 & Manitoba total $\mathrm{N}$ excreted & $\%$ & $\mathrm{P}, \mathrm{B}, \mathrm{D}, \mathrm{Po}$ & $1-$ (Eq. 23 / Eq. 15) \\
\hline 26 & $\mathrm{~N}$ excreted per place per cycle & $\mathrm{kg} \mathrm{cycle}^{-1}$ & $\mathrm{P}, \mathrm{B}, \mathrm{D}, \mathrm{Po}$ & Eq. $25 \times$ Eq. 15 \\
\hline 27 & $\mathrm{~N}$ excreted per place per year & kg year $^{-1}$ & B, Po & Eq. $26 \times$ Input 6 \\
\hline & & & $\mathrm{P}, \mathrm{D}$ & Eq. $26 \times$ Constant 22 \\
\hline 28 & $\mathrm{~N}$ excreted per herd or flock per year & kg year $^{-1}$ & $\mathrm{P}, \mathrm{B}, \mathrm{D}, \mathrm{Po}$ & Eq. $27 \times$ Input 2 \\
\hline 29 & $\mathrm{~N}$ excreted per herd or flock adjusted for $\mathrm{N}$ loss & $\mathrm{kg} \mathrm{N}$ year $^{-1}$ & $\mathrm{P}, \mathrm{B}, \mathrm{D}, \mathrm{Po}$ & Eq. $28 \times$ Input 1 \\
\hline 30 & Manitoba total P excreted & $\%$ & $\mathrm{P}, \mathrm{B}, \mathrm{D}, \mathrm{Po}$ & $1-$ (Eq. 24 / Eq. 16) \\
\hline 31 & P excreted per place per cycle & $\mathrm{kg} \mathrm{cycle}^{-1}$ & $\mathrm{P}, \mathrm{B}, \mathrm{D}, \mathrm{Po}$ & Eq. $16 \times$ Eq. 30 \\
\hline 32 & $\mathrm{P}_{2} \mathrm{O}_{5}$ excreted per place per cycle & $\mathrm{kg} \mathrm{cycle}^{-1}$ & $\mathrm{P}, \mathrm{B}, \mathrm{D}, \mathrm{Po}$ & Eq. $31 \times$ Constant 20 \\
\hline 33 & $\mathrm{P}_{2} \mathrm{O}_{5}$ excreted per place per year & $\mathrm{kg}_{\text {year }}{ }^{-1}$ & B, Po & Eq. $32 \times$ Constant 22 \\
\hline & & & $\mathrm{P}, \mathrm{D}$ & Eq. $32 \times$ Input 6 \\
\hline 34 & $\mathrm{P}_{2} \mathrm{O}_{5}$ excreted per herd or flock per year & kg year $^{-1}$ & $\mathrm{P}, \mathrm{B}, \mathrm{D}, \mathrm{Po}$ & Eq. $33 \times$ Input 2 \\
\hline [a] Inputs a & re from table 3 , and constants are from table 4. & & & \\
\hline [b] This va & iable is constant 2 (table 4 ) for all pigs except nurs & and grower/finisher. & & \\
\hline [c] Equatio & for nursery and grower/finisher pigs only. & & & \\
\hline [d] Equatio & for all pigs except nursery and grower finisher. & & & \\
\hline & & & & \\
\hline
\end{tabular}


(a) Beef

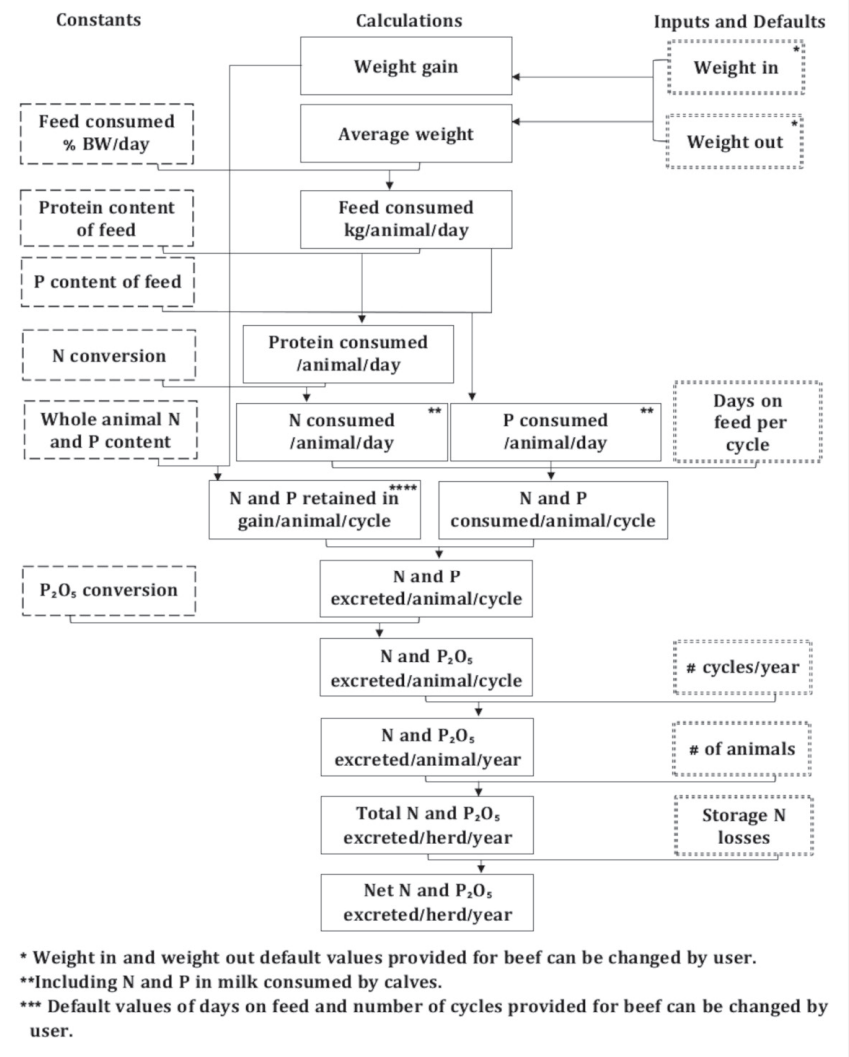

(b) Dairy

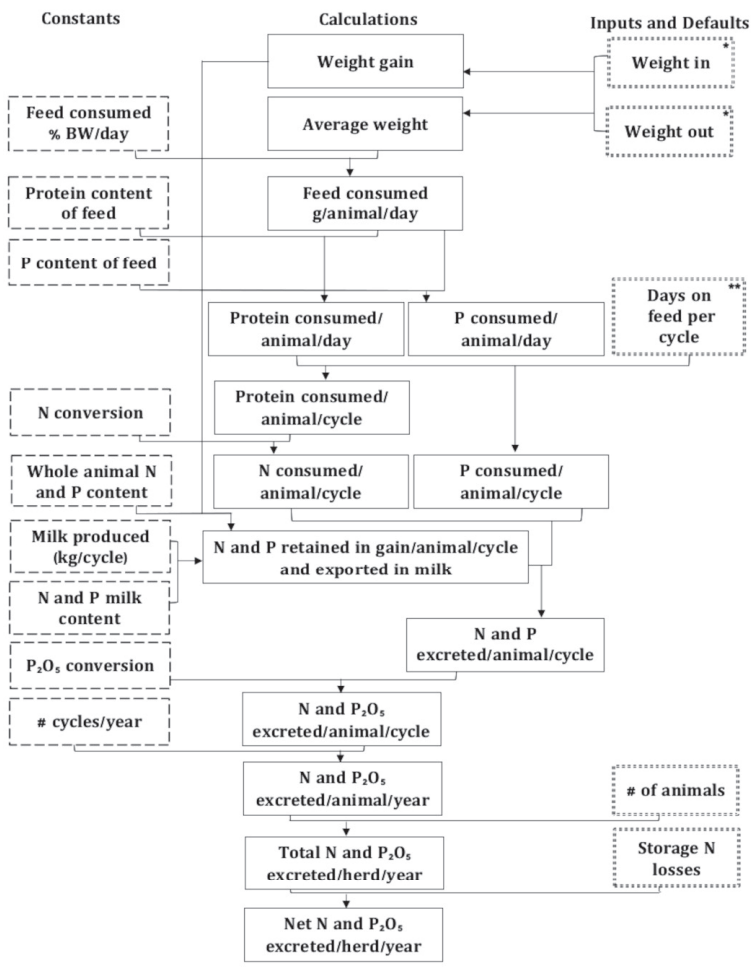

* Weight in and weight out values are constants for dairy and cannot be easily changed by user.

* Days on feed are constant for dairy.

\section{(d) Poultry}

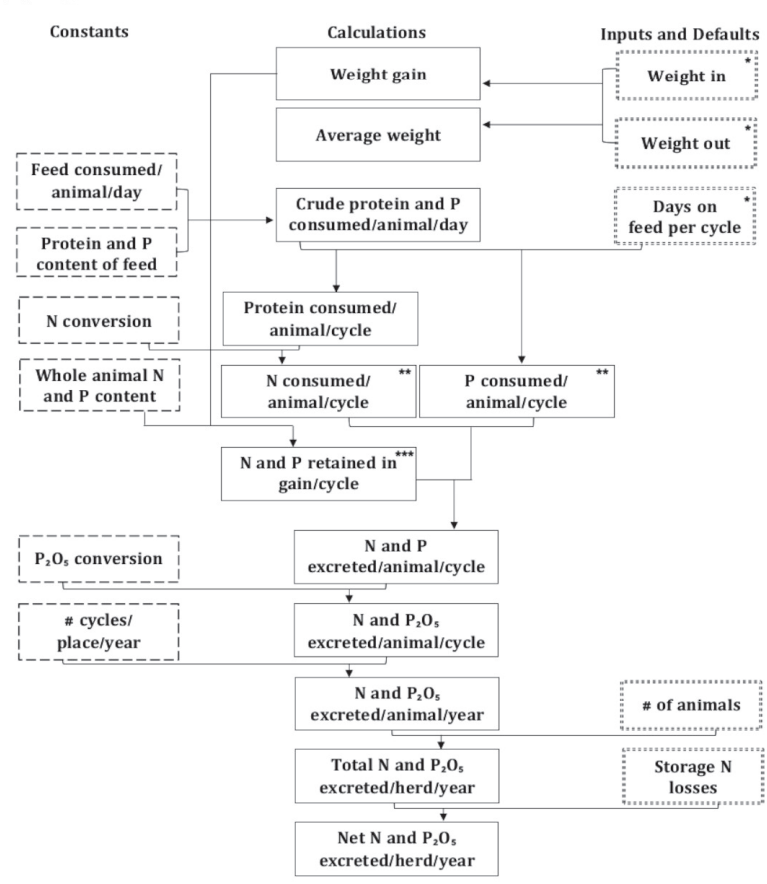

* Weight in, weight out, and days on feed are constants for pigs and cannot be easily changed by user.

${ }^{*}$ Including $\mathrm{N}$ and $\mathrm{P}$ in milk consumed by nursing litter.

*** Including $\mathrm{N}$ and $\mathrm{P}$ in milk produced by nursing sow.

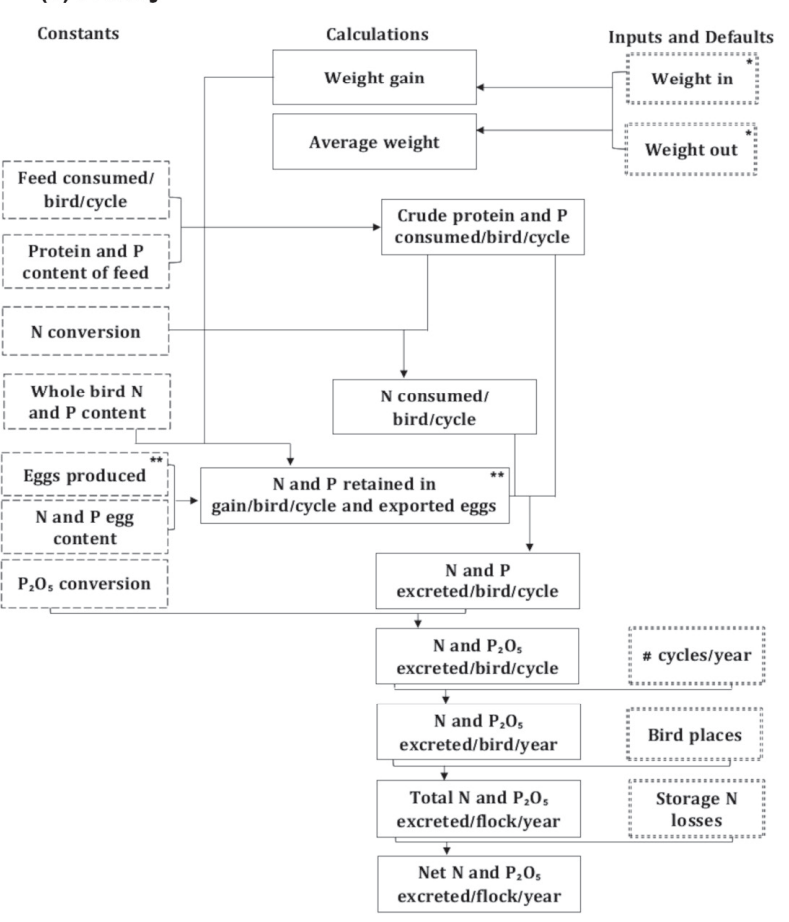

* Weight in and weight out are constants for poultry.

** For layers/breeding operations.

Figure 1. Flowcharts indicating major inputs, constants, and calculations used to estimate nutrient excretion for (a) beef, (b) dairy, (c) pig, and (d) poultry operations. Not all constants are shown in the flowcharts because they are used for transformations or intermediate calculations. 


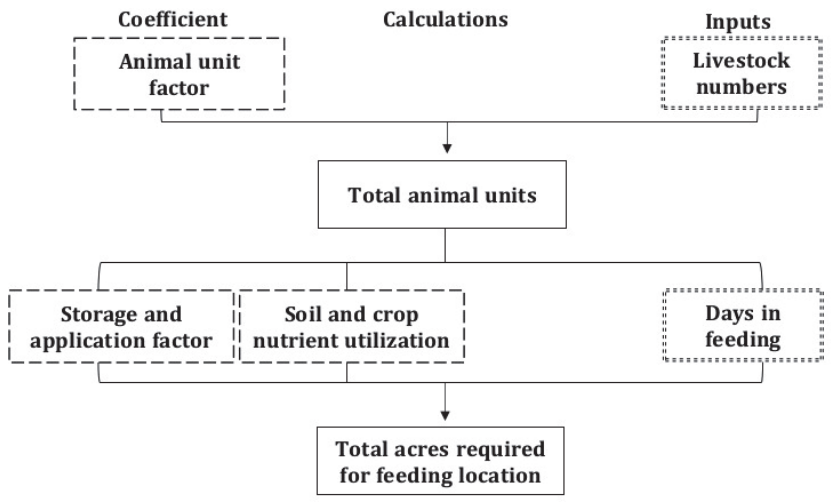

Figure 2. Land area (ha) required for a livestock and poultry operation according to the Farm Practices Guidelines (FPG).

\section{Case Studies Comparing MLC ANd FPG}

Two case studies were used to compare the MLC and the FPG nutrient excretion estimates and the provincial land requirements. A pig operation and a poultry operation were selected from the Livestock Technical Review Public Registry (Manitoba, 2020c).

\section{Pig Operation}

The first case study was a nursery pig operation (24,000 weanlings, equivalent to $792 \mathrm{AU}$ ) comprised of four barns located in southwestern Manitoba. Liquid manure was stored in an outdoor earthen manure storage structure and applied in the fall using partial injection (i.e., Aerway manure application system with tines or coulters that disturb the soil and dribble the manure in a single pass). The cropland area available to the farm consisted of 577 ha distributed among canola (297 ha), soybeans (116 ha), and spring wheat (163 ha) production, with respective long-term average yields from the Manitoba Agricultural Services Corporation (MASC) database (Manitoba, 2020b) of 2.3, 2.6, and $3.5 \mathrm{Mg}$ $\mathrm{ha}^{-1}$ (yields adjusted to $15 \%$ moisture content). The soils in the area are loamy (medium to heavy texture; Manitoba, 2016). For consistency, an FPG soil and crop $\mathrm{N}$ utilization factor of 0.35 was used because the associated crop N utilization $\left(165 \mathrm{~kg} \mathrm{ha}^{-1}\right)$ corresponded most closely to the crop $\mathrm{N}$ utilization generated by the MLC. The earthen manure storage and partial injection resulted in a storage and application coefficient of 0.59 (table 6).

\section{Poultry Operation}

The second case study was a poultry operation located in southeastern Manitoba with a total capacity of 135,000 white laying hens. The operation was equivalent to $1120.5 \mathrm{AU}$. Solid manure was stored in an enclosed solid manure building and was applied primarily in the fall on annual crops via broadcast application and incorporation within $48 \mathrm{~h}$. The cropland associated with the farm consisted of 678 ha distributed among alfalfa (65 ha), canola (153 ha), corn grain (153 ha), soybeans (153 ha), and spring wheat (153 ha). The long-term average yields $\left(9.0 \mathrm{Mg}\right.$ alfalfa ha ${ }^{-1}, 2.89 \mathrm{Mg}$ can-

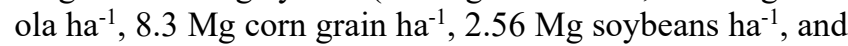
$4.07 \mathrm{Mg}$ spring wheat $\mathrm{ha}^{-1}$ ) were established using the MASC database (yields adjusted to $15 \%$ moisture content; Manitoba, 2020a). The soils in the area are classified as clay
Table 6. Coefficients used to adjust for $\mathbf{N}$ lost from manure storage and application method. ${ }^{[\mathrm{a}]}$

\begin{tabular}{|c|c|c|c|c|}
\hline \multirow[b]{2}{*}{ Manure Storage Method } & \multicolumn{4}{|c|}{ Application Method } \\
\hline & Injection & $\begin{array}{c}\text { Broadcast and } \\
\text { Incorporate } \\
\text { within } 48 \mathrm{~h}\end{array}$ & Broadcast & Sprinkler \\
\hline \multicolumn{5}{|l|}{ Liquid manure systems } \\
\hline Enclosed & 0.83 & 0.81 & 0.64 & 0.60 \\
\hline Open (except earthen) & 0.78 & 0.76 & 0.60 & 0.56 \\
\hline Earthen & 0.59 & 0.57 & 0.45 & 0.42 \\
\hline \multicolumn{5}{|l|}{ Solid manure systems } \\
\hline Daily scrape & & 0.71 & 0.60 & \\
\hline Manure pack & & 0.67 & 0.56 & \\
\hline Open lot & & 0.48 & 0.40 & \\
\hline
\end{tabular}

Table 7. Coefficients used to adjust for soil and nitrogen utilization based on annual applications. ${ }^{[a]}$

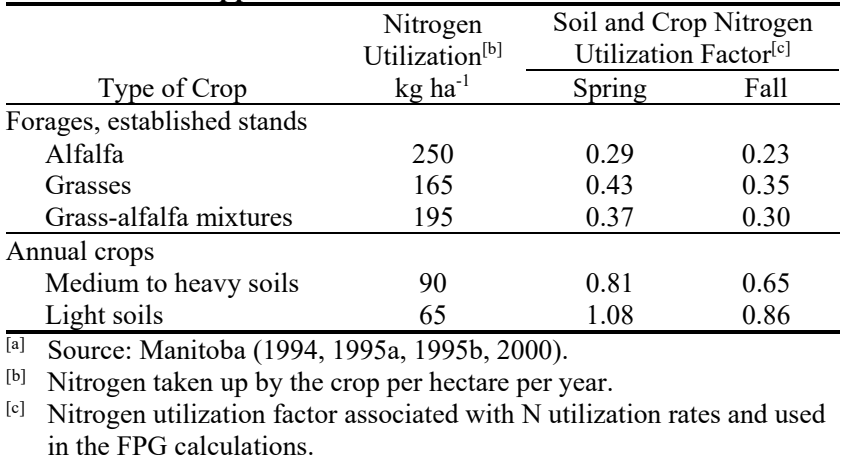

(fine textured; Manitoba, 2016). For consistency, an FPG soil and crop $\mathrm{N}$ utilization co-efficient of 0.30 (table 7) was used because the associated crop $\mathrm{N}$ utilization $\left(195 \mathrm{~kg} \mathrm{ha}^{-1}\right)$ corresponded most closely with the crop $\mathrm{N}$ utilization generated by the MLC. A storage and application coefficient of 0.71 (table 6) was used to reflect practices that most closely resemble those used by the poultry operation.

\section{RESULTS Pig OPERATION}

According to the MLC, 86,507 and 38,795 kg of manure $\mathrm{N}$ and $\mathrm{P}_{2} \mathrm{O}_{5}$, respectively, were produced in the pig facility per year before losses. These amounts corresponded to approximately $48 \%$ and $47 \%$ of the total $\mathrm{N}$ and $\mathrm{P}$ fed, respectively. Nitrogen losses from the barns and earthen manure storage structure were estimated at $25,952 \mathrm{~kg} \mathrm{~N}$. The average crop $\mathrm{N}$ uptake and phosphorus $\left(\mathrm{P}_{2} \mathrm{O}_{5}\right)$ removal were 155 and $41 \mathrm{~kg} \mathrm{ha}^{-1}$, respectively. At the time of approval, the land estimates for this operation were 390 and 937 ha for manure $\mathrm{N}$ and $\mathrm{P}$, respectively. In contrast to the MLC, the AU calculation within the previous FPG methodology estimated $57,816 \mathrm{~kg} \mathrm{~N}$ excreted, of which $23,704 \mathrm{~kg}$ were assumed to be lost from storage and application. This resulted in a land requirement of 164 ha using the previous FPG methodology.

\section{Poultry Operation}

According to the MLC, 81,011 and $53,606 \mathrm{~kg}$ of manure $\mathrm{N}$ and $\mathrm{P}_{2} \mathrm{O}_{5}$, respectively, were produced in the poultry facility per year. These amounts corresponded to 
approximately $59 \%$ and $84 \%$ of the total $\mathrm{N}$ and $\mathrm{P}$ fed, respectively. The $\mathrm{N}$ loss from the barn and solid manure storage building represented $16,202 \mathrm{~kg} \mathrm{~N}$. The average crop $\mathrm{N}$ uptake and $\mathrm{P}_{2} \mathrm{O}_{5}$ removal were 193 and $49 \mathrm{~kg} \mathrm{ha}^{-1}$, respectively. At the time of approval, the land estimates using the MLC were 335 ha for manure $\mathrm{N}$ and 1,091 ha to achieve $\mathrm{P}$ balance. In contrast to the MLC, the AU calculation within the previous FPG methodology estimated $81,796 \mathrm{~kg}$ of $\mathrm{N}$ excreted, of which $23,721 \mathrm{~kg} \mathrm{~N}$ were assumed to be lost during storage and application. This resulted in a land requirement of 239 ha for manure $\mathrm{N}$ using the previous FPG methodology.

\section{DISCUSSION}

For the pig operation case study, the MLC indicated that about $50 \%$ of the nutrients fed to the weanlings was excreted in manure, which is consistent with the range of $30 \%$ to $60 \%$ retention for $\mathrm{N}$ reported in the literature (NRC, 2012). Dourmad et al. (1999) showed an average excretion of $44 \%$ for both $\mathrm{N}$ and $\mathrm{P}$. A review by Millet et al. (2018) reported $\mathrm{N}$ efficiencies of $46 \%$ and a predicted improvement to $57 \%$ for pigs in the finishing stage. Another study in France, The Netherlands, and Denmark reported P excretion of 52\% for weanlings (Poulsen et al., 1999) as a consequence of improved nutrient utilization, resulting in lower excretion when compared to other classes of pigs (e.g., sows with 79\% P excretion). Almeida and Stein (2010) reported $\mathrm{P}$ excretion rates of $45 \%$ of total $\mathrm{P}$ consumed by pigs. It should be noted that $\mathrm{P}$ excretion in manure may be impacted by strategies such as feeding low-bioavailability mineral $\mathrm{P}$ supplements combined with phytase, or feeding high water-soluble $\mathrm{P}$ supplements (Liu et al., 2020). The feeding formulations in the MLC are defined by constants that reflect current industry practices and cannot be changed by the user. This approach was taken to minimize the input requirements and make the tool user-friendly. New feeding strategies may be factored into the MLC if they become widely adopted by industry.

For the poultry operation, the MLC estimated N and P excretions of $59 \%$ and $84 \%$, respectively. These findings are within the ranges reported in a summary of more than 80 peer-reviewed articles over 18 years, demonstrating that $\mathrm{N}$ excretion ranged from $25 \%$ to $70 \%$, while $\mathrm{P}$ excretion ranged from $56 \%$ to $86.4 \%$ (Applegate et al., 2003). A study evaluating $\mathrm{N}$ excretion in layer hens fed a range of dietary crude protein $(17 \%$ to $13 \%)$ demonstrated that $\mathrm{N}$ excretion decreased from $54 \%$ to $49 \%$ as the crude protein content of the diet decreased (Latshaw and Zhao, 2011). A recent local study with laying hens in Manitoba determined that total $\mathrm{P}$ excretion as a percentage of total $\mathrm{P}$ intake ranged from $85 \%$ to $89 \%$ (Jing et al., 2018). The authors concluded that total $\mathrm{P}$ excretion decreased proportionally with reduced total $\mathrm{P}$ intake as a result of decreasing dietary available P. Current feeding practices tend to overestimate the $P$ requirements of livestock and poultry, leading to excess excretion of $P$ in the manure (Jing et al., 2018). The Canadian Food Inspection Agency (Canada, 2021) has proposed modernization of current livestock and poultry feeding regulations, which will allow lower inclusion of dietary $\mathrm{P}$ in animal feeds, creating the potential for reduction of $\mathrm{P}$ excretion in poultry manure.

In addition to using a mass balance approach, one of the most significant differences between the FPG methodology and the MLC is the inclusion of $P$ in the land requirement estimates. Manure application in Manitoba is primarily based on crop $\mathrm{N}$ requirements (Cordeiro et al., 2016), which often results in a buildup of soil test $\mathrm{P}$, increasing the risk of P loss to surface water and accelerated eutrophication (Withers et al., 2019). As a result, Manitoba adopted regulations that allow manure to be applied based on $\mathrm{N}$ until soils reach a concentration of $60 \mathrm{mg} \mathrm{kg}^{-1}$ of Olsen soil test P (Manitoba, 1998a). At this point, application rates must account for $\mathrm{P}$ removal by crops. Phosphorus application rates are typically much lower than $\mathrm{N}$ application rates, resulting in a much larger land area required for P-based manure application (Menzi et al., 2010).

The crop nutrient utilization and removal components were also expanded in the MLC because the FPG contained a narrow range of crop types and $\mathrm{N}$ utilization only (table 7). The MLC contains crop data for 20 of the most common crops grown in Manitoba. Crop nutrient utilization and removals are calculated based on operation-specific rotations, realistic long-term yields, and land available to the operation. The volatilization losses used in the MLC have not been updated significantly, using generic estimates of in-barn and storage losses adapted from the FPG.

As a result of the improvements discussed above, the MLC typically generates larger land requirements for manure application than the FPG, as illustrated by the pig and poultry case studies presented here. For the pig operation case study, the MLC increased the $\mathrm{N}$ land requirement by 2.4-fold compared to the FPG methodology. This increase was primarily due to the larger estimate of excreted $\mathrm{N}$ by the MLC $\left(86,507 \mathrm{~kg} \mathrm{year}^{-1}\right)$ compared to the FPG $(57,816 \mathrm{~kg}$ year $\left.^{-1}\right)$. The FPG N excretion estimate was similar to that of the 1993 ASABE Standard $\left(61,495 \mathrm{~kg} \mathrm{year}^{-1}\right)$. This is to be expected because the FPG AU calculation incorporated early ASABE estimates. The value reported in the current 2005 ASABE Standard $(0.41 \mathrm{~kg} \mathrm{~N}$ excreted per finished weanling) generates $9,840 \mathrm{~kg} \mathrm{~N}$ excreted by 24,000 weanlings finished in 36 days (per cycle). If the operation runs nine cycles in a year, then $88,560 \mathrm{~kg} \mathrm{~N}_{\text {year }}{ }^{-1}$ would be excreted, indicating that the ASABE N excretion estimates increased between 1993 and 2005 and are much closer to the MLC.

Notably, the 2005 ASABE Standard provides excretion as a total for each production phase to avoid misuse of daily average values (ASABE, 2005). However, production-phase excretion totals are dependent on the parameters used for calculation and should only be used if the operation meets those criteria. For example, the typical values for nursery pigs in the 2005 ASABE Standard assume that the piglets are fed for 36 days and have an average weight of $12.5 \mathrm{~kg}$, whereas the MLC assumes that nursery pigs are fed for 52 days and have an average weight of $17 \mathrm{~kg}$. The MLC assumptions were based on 2016 production practices in Manitoba. Current trends are toward longer cycles, typically eight or nine weeks (Tricia Schmalenberg, Maple Leaf AgriFarms, personal communication, 2 Feb. 2021; Matthew 
Reimer, HyLife, personal communication, 2 Feb. 2021), although the exact cycle length can be influenced by the finisher space available. Continuous changes in production practices reinforce the need to update models regularly or develop flexible tools that can be adjusted by the user, as appropriate.

Despite the larger $\mathrm{N}$ excretion estimated by the MLC, N losses by volatilization from the barn and storage $(25,952 \mathrm{~kg}$ year ${ }^{-1}$ ) were similar to those estimated by the FPG $\left(23,704 \mathrm{~kg}\right.$ year $\left.^{-1}\right)$, presumably because the MLC adapted volatilization estimates from the FPG. In addition, the crop $\mathrm{N}$ utilization factors chosen for the FPG simulation were as close as possible to the more accurate $\mathrm{N}$ utilization values generated by the MLC to account for known changes in crops and increases in yields over the last 20 years.

In contrast to the pig case study, the estimates of $\mathrm{N}$ excretion from the poultry operation were similar for the MLC $\left(81,011 \mathrm{~kg}\right.$ year $\left.^{-1}\right)$ and the FPG $\left(81,796 \mathrm{~kg} \mathrm{year}^{-1}\right)$. The 2005 ASABE Standard reports N excretion for layers as $0.0016 \mathrm{~kg}$ $\mathrm{N}$ excreted per animal per day, resulting in yearly $\mathrm{N}$ excretion of 77,112 kg year-1 for 135,000 layers if the barn is filled to capacity for 357 days of the year (as in the MLC), a value that is similar for both the MLC and FPG estimates. Differences in $\mathrm{N}$ losses due to volatilization between the MLC and the FPG resulted in a land base requirement for $\mathrm{N}$ that was 1.4-fold larger with the MLC than with the FPG.

When $\mathrm{P}$ was considered in the land calculations, the land requirements increased substantially, regardless of operation type. The land needed to balance the pig manure $\mathrm{P}$ with crop $\mathrm{P}$ removal increased the land estimate for the nursery by 5.7-fold when compared to the FPG land requirement for $\mathrm{N}$. This increase is in agreement with previous findings reported in the literature for Manitoba (Salvano et al., 2004). There are no $\mathrm{P}$ losses in the MLC; therefore, the $\mathrm{P}$ land requirement is based solely on P excretion. The 2005 ASABE Standard estimates that $0.068 \mathrm{~kg} P$ are excreted per finished weanling, resulting in $3,737 \mathrm{~kg} \mathrm{P}_{2} \mathrm{O}_{5}$ for 24,000 weanlings finished in 36 days. If the operation runs nine cycles in a year, then $33,635 \mathrm{~kg} \mathrm{P}_{2} \mathrm{O}_{5}$ year $^{-1}$ are excreted, indicating that the ASABE P excretion estimate was approximately $15 \%$ lower than the MLC estimate $(38,795 \mathrm{~kg})$ for $\mathrm{P}_{2} \mathrm{O}_{5}$ excretion.

For the poultry operation, the $\mathrm{P}$ land requirement increased by 4.6 -fold compared to the N-based FPG estimate. The 2005 ASABE Standard reports $P$ excretion for layers at $0.00048 \mathrm{~kg} \mathrm{P}$ per animal per day, resulting in yearly $\mathrm{P}_{2} \mathrm{O}_{5}$ excretion of 52,975 kg year ${ }^{-1}$ for 135,000 layers if the barn is filled to capacity for 357 days of the year, which is very similar to the MLC estimate of 53,606 kg for $\mathrm{P}_{2} \mathrm{O}_{5}$ excretion. Increases in land requirements for balancing $\mathrm{P}$ application and removal should be acknowledged when planning livestock and poultry expansion because more land may be needed over time to avoid excessive buildup of soil $\mathrm{P}$.

The MLC does not include the impact of manure treatment on land requirements because manure treatment systems are not common in Manitoba. In most areas of Manitoba, manure nutrients can be land-applied sustainably using beneficial management practices, including sustainable application rates. Moreover, assessments of different manure treatment technologies, such as manure composting and separation, indicated that the efficacy of these treatments was low due to the cold climate conditions prevailing in Manitoba, variability in manure composition, and economic constraints (Ackerman and Cicek, 2013; Agnew et al., 2010; Kotyk and Grieger, 2014). However, as livestock and poultry production intensify in specific regions of the province, the land available for manure application becomes more limited. In these regions, manure must be transported greater distances, and manure treatment may become more attractive.

\section{CONCLUSIONS}

The Manitoba Land Calculator (MLC) is an adaptable and user-friendly tool developed in the Province of Manitoba, Canada, to estimate land requirements for new and expanding livestock and poultry operations. The MLC estimates land requirements for $\mathrm{N}$ and $\mathrm{P}$ based on Manitoba-specific livestock and poultry production practices and animal performance. It uses a mass balance approach to estimate livestock and poultry nutrient excretion and incorporates operation-specific estimates of crop nutrient utilization and removals. Two case studies comparing the MLC to the previous FPG methodology used in Manitoba showed land requirements based on $\mathrm{N}$ to be 1.4 to 1.5 times greater when using the MLC. However, to achieve $\mathrm{P}$ balance, as much as 4 to 6 times more land may be needed than was required using the N-based FPG methodology of the 1990s and early 2000s. Awareness of the land requirements for $\mathrm{P}$ balance during the planning stages is necessary to ensure that livestock and poultry operations have access to sufficient land within economical transport distances from the operation. Sufficient land enables producers to apply manure at rates following $4 \mathrm{R}$ nutrient stewardship principles, which reduces the risk of losing surplus nutrients to surface and groundwater.

\section{ACCESSING THE MLC}

The Manitoba Land Calculator (MLC) is available for download at the Manitoba Agriculture and Resource Development website (Manitoba, 2020a). The downloadable version of the MLC supports applications for new and expanding livestock and poultry operations. The MLC requires limited data entry from the user; however, most of the calculations and variables are hidden from the user and cannot be changed. A copy of the MLC in open format may be requested from Manitoba Agriculture and Resource Development for research purposes.

\section{ACKNOWLEDGEMENTS}

The authors would like to acknowledge the following people and organizations for their contributions to the development of the MLC: Robyn Harte, Amy Johnston, Robert Berry, Brian Wiebe, Getahun Gizaw (all from Manitoba Agriculture and Resource Development), Emma McGeough (University of Manitoba), HyLife Ltd., Maple Leaf AgriFarms, Sollio Agriculture, and Trouw Nutrition Canada and Masterfeeds. 


\section{REFERENCES}

Ackerman, J., \& Cicek, N. (2013). Separated manure solids: Technical and economic evaluation of beneficial management practices. Winnipeg, MB, Canada: Manitoba Livestock Manure Management Initiative. Retrieved from http://www.manure.mb.ca/projects/viewproject.php?id=90

Adeyeye, E. I. (2009). Comparative study on the characteristics of egg shells of some bird species. Bull. Chem. Soc. Ethiopia, 23(2), 159-166. https://doi.org/10.4314/bcse.v23i2.44957

Agnew, J., Grieger, L., \& Chorney, H. (2010). Literature review: Summary of manure treatment technologies and their impact on the manure phosphorus balance. Winnipeg, MB, Canada: Manitoba Livestock Manure Management Initiative. Retrieved from http://www.manure.mb.ca/projects/viewproject.php?id=79

Alexandratos, N., \& Bruinsma, J. (2012). World agriculture towards 2030/2050: The 2012 revision. FAO ESA Working Paper No. 12-03. Rome, Italy: United Nations FAO. Retrieved from https://ageconsearch.umn.edu/record/288998/

Almeida, F. N., \& Stein, H. H. (2010). Performance and phosphorus balance of pigs fed diets formulated on the basis of values for standardized total tract digestibility of phosphorus. J. Animal Sci., 88(9), 2968-2977. https://doi.org/10.2527/jas.2009-2285

Andersen, D. S., \& Pepple, L. M. (2017). A county-level assessment of manure nutrient availability relative to crop nutrient capacity in Iowa: Spatial and temporal trends. Trans. ASABE, 60(5), 1669-1680. https://doi.org/10.13031/trans.12417

Andrew, S. M., Waldo, D. R., \& Erdman, R. A. (1994). Direct analysis of body composition of dairy cows at three physiological stages. J. Dairy Sci., 77(10), 3022-3033. https://doi.org/10.3168/jds.S0022-0302(94)77244-1

Angel, R., Applegate, T. J., \& Bastyr, A. S. (2003). Comparison of two methods for estimating broiler manure nutrient excretion: Biological mass balance versus model based on mass balalnce apporach. Proc. 9th Intl. Animal, Agricultural, and Food Processing Wastes (pp. 303-309). St. Joseph, MI: ASABE. https://doi.org/10.13031/2013.15265

Applegate, T. J., Potturi, L. P., \& Angel, R. (2003). Model for estimating poultry manure nutrient excretion: A mass balance approach. Proc. 9th Intl. Symp. Animal, Agricultural and Food Processing Wastes (pp. 296-302). St. Joseph, MI: ASABE. https://doi.org/10.13031/2013.15264

Applegate, T., Adedokun, S., Powers, W., \& Angel, R. (2008). Determination of nutrient mass balance in turkeys. Poultry Sci., 87(12), 2477-2485. https://doi.org/10.3382/ps.2008-00056

ASABE. (2003). D384.1: Manure production and characteristics. St. Joseph, MI: ASABE.

ASABE. (2005). D384.2: Manure production and characteristics. St. Joseph, MI: ASABE.

Bikker, P., \& Blok, M. C. (2017). Phosphorus and calcium requirements of growing pigs and sows. Wageningen, Netherlands: Wageningen Universtity and Research. https://doi.org/10.18174/424780

Canada. (2020). CANSIM Table 32-10-0155-01: Selected livestock and poultry, historical data. Ottawa, ON, Canada: Statistics Canada. Retrieved from https://www150.statcan.gc.ca/t1/tbl1/en/cv.action?pid=3210015 501

Canada. (2021). Guide to timelines for complying with the Feeds Regulations, 2021. Ottawa, ON, Canada: Retrieved from https:/www.inspection.gc.ca/animal-health/livestockfeeds/consultations/guide-totimelines/eng/1601049242151/1601049242561

CanWest DHI. (2018). 2018 Western progress report. Guelph, ON, Canada: CanWest DHI. Retrieved from http://www.canwestdhi.com/flipwest18/mobile/index.html\#p=1
Cordeiro, M. R., Lobb, D. A., Flaten, D. N., \& Wilson, H. (2016). Beneficial management practices for the application of manure on tile-drained lands: A review of literature. Winnipeg, MB, Canada: Manitoba Livestock Manure Management Inititative. Retrieved from http://www.manure.mb.ca/projects/viewproject.php?id=102

Csapó, J., Martin, T. G., Csapo-Kiss, Z. S., \& Hazas, Z. (1996). Protein, fats, vitamin and mineral concentrations in porcine colostrum and milk from parturition to 60 days. Intl. Dairy J., 6(8-9), 881-902. https://doi.org/10.1016/0958-6946(95)00072-0

de Avila, V. S., Penz Jr, A. M., Rosa, P. S., de Brum, P. A., Guidoni, A. L., \& Ledur, M. C. (2003). Influence of feeding time on sexual maturity and carcass composition in female broiler breeders. Brazilian J. Poultry Sci., 5(3), 189-196. https://doi.org/10.1590/S1516-635X2003000300006

Delgado, J. A., Short, N. M., Roberts, D. P., \& Vandenberg, B. (2019). Big data analysis for sustainable agriculture on a geospatial cloud framework. Front. Sustain. Food Syst., 3, article 54. https://doi.org/10.3389/fsufs.2019.00054

Dinnes, D. L., Karlen, D. L., Jaynes, D. B., Kaspar, T. C., Hatfield, J. L., Colvin, T. S., \& Cambardella, C. A. (2002). Nitrogen management strategies to reduce nitrate leaching in tile-drained Midwestern soils. Agron. J., 94(1), 153-171.

https://doi.org/10.2134/agronj2002.1530

dos Santos, A. L., de Faria, D. E., de Oliveira, R. P., Pavesi, M., \& Silva, M. F. (2017). Growth and body composition of laying hens under different feeding programs up to 72 weeks. J. Animal Sci. Res., 1(1). https://doi.org/10.16966/2576-6457.103

Dourmad, J.-Y., Sève, B., Latimier, P., Boisen, S., Fernandez, J., Van der Peet-Schwering, C., \& Jongbloed, A. W. (1999). Nitrogen consumption, utilisation, and losses in pig production in France, The Netherlands, and Denmark. Livestock Prod. Sci., 58(3), 261-264. https://doi.org/10.1016/S0301-6226(99)00015-9

Ghane, A. E., Duncan, I. J., \& Bédécarrats, G. Y. (2015). Changes in physical and chemical characteristics of turkey eggs throughout a laying cycle. J. Appl. Poultry Res., 24(4), 520-528. https://doi.org/10.3382/japr/pfv040

Gibson, C. P., Horn, G. W., \& Krehbiel, C. R. (2002). Soil phosphorus removal by stocker cattle grazing winter wheat. Animal Science Research Report. Stillwater, OK: Oklahoma State University, Oklahoma Agricultural Experiment Station.

Godwin, J. L., Grimes, J. L., Christensen, V. L., \& Wineland, M. J. (2005). Effect of dietary phosphorus and phytase levels on the reproductive performance of large white turkey breeder hens. Poultry Sci., 84(3), 485-493. https://doi.org/10.1093/ps/84.3.485

Goselink, R. M., Klop, G., Dijkstra, J., \& Bannink, A. (2015). Phosphorus metabolism in dairy cattle: Literature study on recent developments and gaps in knowledge. Wageningen, Netherlands: Wageningen UR Livestock Research.

Halley, J. (2016). Breeder nutrition for modern broiler breeders. Huntsville, AL: Aviagen Inc. Retrieved from https://agbio.usask.ca/nserc-irc/documents/2016-aviagenmeeting/johnhalleybreedernutrition.pdf

Hidiroglou, M., \& Proulx, J. G. (1982). Factors affecting the calcium, magnesium, and phosphorus content of beef cow milk. Canadian J. Comp. Med., 46(2), 212-214.

Jing, M., Zhao, S., Rogiewicz, A., Slominski, B. A., \& House, J. D. (2018). Assessment of the minimal available phosphorus needs of laying hens: Implications for phosphorus management strategies. Poultry Sci., 97(7), 2400-2410. https://doi.org/10.3382/ps/pey057

Koelsch, R. K. (2006). Updated ASABE Standard Manure Excretion Standard. St. Joseph, MI: ASABE. Retrieved from https://digitalcommons.unl.edu/biosysengpres/6

Kopp, J. C., Wittenberg, K. M., \& McCaughey, W. P. (2004). Management strategies to improve cow-calf productivity on 
meadow bromegrass pastures. Canadian J. Animal Sci., 84(3), 529-535. https://doi.org/10.4141/A03-092

Kotyk, L., \& Grieger, L. (2014). Evaluation of a fine mesh screen manure treatment technology under Manitoba conditions. Winnipeg, MB, Canada: Manitoba Livestock Manure Management Initiative. Retrieved from http://www.manure.mb.ca/projects/viewproject.php?id=95

Lambert, W., Van Krimpen, M. M., \& Star, L. (2014). Phosphorus requirement in laying hens. Lelystad, Netherlands: Schothorst Feed Research. Retrieved from https://library.wur.nl/WebQuery/wurpubs/482706

Latshaw, J. D., \& Zhao, L. (2011). Dietary protein effects on hen performance and nitrogen excretion. Poultry Sci., 90(1), 99-106. https://doi.org/10.3382/ps.2010-01035

Liu, L., Guo, Y., Tu, Y., Zhang, N., Bai, Z., Chadwick, D., ... Ma, L. (2020). A higher water-soluble phosphorus supplement in pig diet improves the whole-system phosphorus use efficiency. $J$. Cleaner Prod., 272, 122586. https://doi.org/10.1016/j.jclepro.2020.122586

Liu, Q., Wang, J., Bai, Z., Ma, L., \& Oenema, O. (2017). Global animal production and nitrogen and phosphorus flows. Soil Res., 55(6), 451-462. https://doi.org/10.1071/SR17031

Long, C. M., Muenich, R. L., Kalcic, M. M., \& Scavia, D. (2018). Use of manure nutrients from concentrated animal feeding operations. J. Great Lakes Res., 44(2), 245-252. https://doi.org/10.1016/j.jglr.2018.01.006

Loro, P., Arzandeh, M., Brewin, D., Akinremi, W., Gyles, C., \& Ige, D. (2013). Estimating soil phosphorus budgets for rural municipalities in Manitoba. Winnipeg, MB, Canada: Manitoba Livestock Manure Management Initiative. Retrieved from http://manure.mb.ca/projects/pdfs/Final\%20Report\%202010-19L\%20Estimating\%20Soil\%20Phosphorus\%20Budgets\%20by\% 20Municipality.pdf

Lory, J. A., Massey, R., \& Joem, B. C. (2008). Using manure as a fertilizer for crop production. In Final report: Gulf hypoxia and local water quality concerns workshop (pp. 105-116). St. Joseph, MI: ASABE. https://doi.org/10.13031/2013.24247

Manitoba. (1994). Farm practices guidelines for beef producers in Manitoba. Winnipeg, MB, Canada: Manitoba Agriculture and Resource Development.

Manitoba. (1995a). Farm practices guidelines for dairy producers in Manitoba. Winnipeg, MB, Canada: Manitoba Agriculture and Resource Development.

Manitoba. (1995b). Farm practices guidelines for hog producers in Manitoba. Winnipeg, MB, Canada: Manitoba Agriculture and Resource Development.

Manitoba. (1998a). Farm practices guidelines for hog producers in Manitoba. Winnipeg, MB, Canada: Manitoba Agriculture and Resource Development.

Manitoba. (1998b). The Environment Act: Livestock Manure and Mortalities Management Regulation MR42/98. Winnipeg, MB, Canada: Government of Manitoba.

Manitoba. (2000). Farm practices guidelines for poultry producers in Manitoba. Winnipeg, MB, Canada: Manitoba Agriculture and Resource Development.

Manitoba. (2009). Manure management facts: Managing manure within tillage systems and crop rotations. Winnipeg, MB, Canada: Manitoba Agriculture, Food, and Rural Initiatives. Retrieved from https://www.manitoba.ca/agriculture/environment/nutrientmanagement/pubs/mmf_manuretillage_factsheet.pdf

Manitoba. (2013). Manitoba swine nutrition 2013 survey. Winnipeg, MB, Canada: Manitoba Livestock Manure Management Initiative (MLMMI). Retrieved from http://manure.mb.ca/projects/pdfs/1_Manitoba\%20Swine $\% 20 \mathrm{~N}$ utrition\%202013\%20Survey\%20Final\%20Report.pdf
Manitoba. (2016). AgriMaps: A soil viewer/web map by Manitoba Agriculture. Retrieved from

https://www.arcgis.com/home/item.html?id=b070d38c42324b5a $82501 \mathrm{a} 02 \mathrm{cfd} 744 \mathrm{e} 7$

Manitoba. (2019). The Manitoba protein advantage: A strategy for sustainable protein production, processing and innovation. Winnipeg, MB, Canada: Manitoba Agriculture and Resource Development. Retrieved from

https://www.gov.mb.ca/agriculture/protein/pubs/manitobaprotein-strategy.pdf

Manitoba. (2020a). Land base requirements for new and expanding livestock operations. Winnipeg, MB, Canada: Manitoba Agriculture and Resource Development. Retrieved from https://www.gov.mb.ca/agriculture/environment/nutrientmanagement/land-base-requirements-for-new-and-expandinglivestock-operations.html

Manitoba. (2020b). MMPP - Variety yield data browser. Portage La Prairie, MB, Canada: Manitoba Agricultural Services Corporation. Retrieved from https://www.masc.mb.ca/masc.nsf/mmpp_browser_variety.html

Manitoba. (2020c). Municipal relations: Public registry. Winnipeg, MB, Canada: Government of Manitoba. Retrieved from https://www.gov.mb.ca/mr/livestock/public_registries.html

Manitoba. (2021a). Manure management. Winnipeg, MB, Canada: Manitoba Agriculture and Resource Development. Retrieved from https://www.gov.mb.ca/agriculture/environment/nutrientmanagement/manure-management.html

Manitoba. (2021b). Egg nutrients. Winnipeg, MB, Canada: Manitoba Egg Farmers. Retrieved from https://www.eggs.mb.ca/about-eggs/egg-nutrition

Marcondes, M. I., Rodrigues Paulino, P. V., Valadares Filho, S. C., Gionbelli, M. P., Costa e Silva, L. F., \& Tedeschi, L. (2010). Chapter 4: Prediction of body and carcass chemical composition of purebred and crossbred Nellore cattle. In Nutrient requirements of Zebu beef cattle (2nd Ed., pp. 61-79). São Carlos, SP, Brazil: Suprema Gráfica e Editora.

Menzi, H., Oenema, O., Burton, C., Shipin, O., Gerber, P., Robinson, T., \& Franceschini, G. (2010). Impacts of intensive livestock production and manure management on the environment. Livestock Changing Landscape, 1, 139-163.

Millet, S., Aluwé, M., Van den Broeke, A., Leen, F., De Boever, J., $\&$ De Campeneere, S. (2018). Pork production with maximal nitrogen efficiency. Animal, 12(5), 1060-1067. https://doi.org/10.1017/S1751731117002610

Mottet, A., de Haan, C., Falcucci, A., Tempio, G., Opio, C., \& Gerber, P. (2017). Livestock: On our plates or eating at our table? A new analysis of the feed/food debate. Global Food Security, 14, 1-8. https://doi.org/10.1016/j.gfs.2017.01.001

NRC. (2001). Nutrient requirements of dairy cattle (7th Ed.). Washington, DC: National Research Council. https://doi.org/10.17226/9825

NRC. (2012). Nutrient requirements of swine (11th Ed.). Washington, DC: National Research Council. https://doi.org/10.17226/13298

Neijat, M., House, J. D., Guenter, W., \& Kebreab, E. (2011). Calcium and phosphorus dynamics in commercial laying hens housed in conventional or enriched cage systems. Poultry Sci., 90(10), 2383-2396. https://doi.org/10.3382/ps.2011-01401

Noblet, J., \& Etienne, M. (1989). Estimation of sow milk nutrient output. J. Animal Sci., 67(12), 3352-3359. https://doi.org/10.2527/jas1989.67123352x

Ontkean, G. R., Volf, C. A., Bennett, D. R., Nolan, S. C., Chanasyk, D. S., \& Miller, J. J. (2006). Phosphorus losses in simulated rainfall runoff from manured land. In Alberta soil phosphorus limits project: Volume 3. Soil sampling, manure application, and 
sorption characteristics. Lethbridge, AB, Canada: Alberta Agriculture, Food and Rural Development.

PIC. (2013). Sow and gilt management manual. Hendersonville, TN: Pig Improvement Company.

Plaizier, J. C., Garner, T., Droppo, T., \& Whiting, T. (2004). Nutritional practices on Manitoba dairy farms. Canadian J. Animal Sci., 84(3), 501-509. https://doi.org/10.4141/A03-115

Poulsen, H. D., Jongbloed, A. W., Latimier, P., \& Fernández, J. A. (1999). Phosphorus consumption, utilisation, and losses in pig production in France, The Netherlands, and Denmark. Livestock Prod. Sci., 58(3), 251-259. https://doi.org/10.1016/S03016226(99)00013-5

Power, J., \& Schepers, J. S. (1989). Nitrate contamination of groundwater in North America. Agric. Ecosyst. Environ., 26(34), 165-187. https://doi.org/10.1016/0167-8809(89)90012-1

Robinson, F. E., \& Robinson, N. A. (1991). Reproductive performance, growth rate, and body composition of broiler breeder hens differing in body weight at 21 weeks of age. Canadian J. Animal Sci., 71(4), 1223-1231. https://doi.org/10.4141/cjas91-145

Rotz, C. A., Corson, M. S., Chianese, D. S., Montes, F., Hafner, S. D., \& Coiner, C. U. (2012). The Integrated Farm System Model (IFSM): References manual, Version 3. University Park, PA: USDA-ARS Pasture Systems and Watershed Management Research Unit.

Salvano, E., Tyrchniewicz, E., \& Flaten, D. N. (2004). Beneficial management practices for the application of manure on tiledrained lands: A review of literature. Winnipeg, MB, Canada: Manitoba Livestock Manure Management Inititative. Retrieved from http://www.manure.mb.ca/projects/viewproject.php?id=102

Shastak, Y., Witzig, M., \& Rodehutscord, M. (2012). Whole-body phosphorus to tibia phosphorus ratio in broilers. Archiv für Geflügelkunde, 76(4), 217-222.
Subbotin, I., Briukhanov, A., \& Vasilev, E. (2017). Factor analysis of environmental impact of manure utilization. Eng. Rural Devel.: Proc., 625-629. https://doi.org/10.22616/ERDev2017.16.N124

Tamminga, S. (2006). Environmental impacts of beef cattle. Proc. John M. Airy Symp.: Visions for Animal Agriculture and the Environment.

Thayer, C. A., Gilley, J. E., Durso, L. M., \& Marx, D. B. (2012) Runoff nutrient loads as affected by residue cover, manure application rate, and flow rate. Trans. ASABE, 55(1), 249-258. https://doi.org/10.13031/2013.41252

van Dijk, K. C., Lesschen, J. P., \& Oenema, O. (2016). Phosphorus flows and balances of the European Union member states. Sci. Total Environ., 542(B), 1078-1093. https://doi.org/10.1016/j.scitotenv.2015.08.048

Velthof, G. L., Lesschen, J. P., Webb, J., Pietrzak, S., Miatkowski, Z., Pinto, M., ... Oenema, O. (2014). The impact of the nitrates directive on nitrogen emissions from agriculture in the EU-27 during 2000-2008. Sci. Total Environ., 468-469, 1225-1233. https://doi.org/10.1016/j.scitotenv.2013.04.058

Withers, P. J., Forber, K. G., Lyon, C., Rothwell, S., Doody, D. G., Jarvie, H. P., ... Cassidy, R. (2019). Towards resolving the phosphorus chaos created by food systems. Ambio, 49(5), 10761089. https://doi.org/10.1007/s13280-019-01255-1

Yang, Q., Tian, H., Li, X., Ren, W., Zhang, B., Zhang, X., \& Wolf, J. (2016). Spatiotemporal patterns of livestock manure nutrient production in the conterminous United States from 1930 to 2012. Sci. Total Environ., 541, 1592-1602. https://doi.org/10.1016/j.scitotenv.2015.10.044

Yurchak, T., \& Okine, E. (2004). Beef ration rules of thumb. Edmonton, AB, Canada: Alberta Agriculture Food and Rural Development. Retrieved from https://open.alberta.ca/dataset/1ecf114e-04c5-42bf-a9f6cb0a26888eb9/resource/13f4426e-75c1-411f-b1270b059338e849/download/2004-420-52-4.pdf 